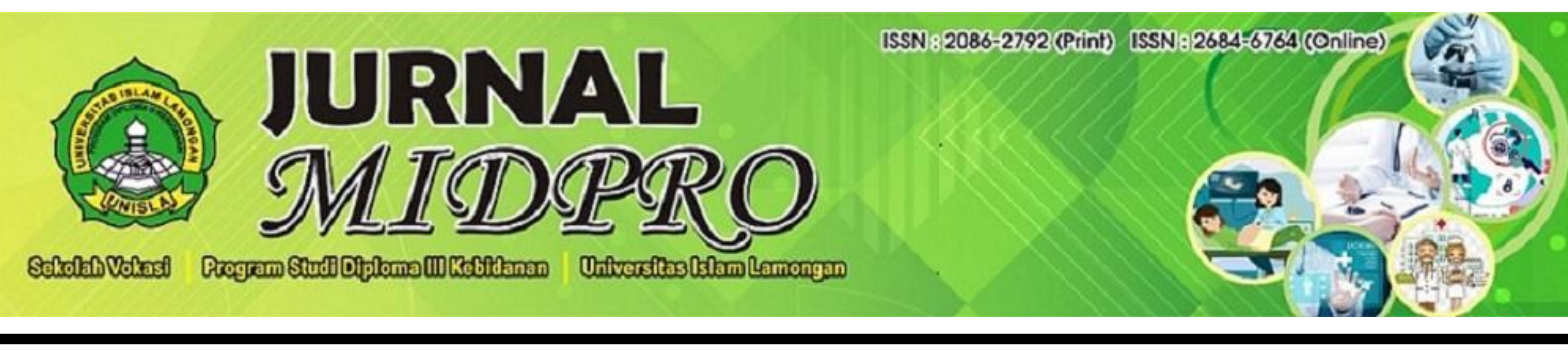

\title{
Qualitative and Quantitative Analysis of Hydroquinone in Face Cream with TLC and
} HPLC Methods

\author{
Rahma Dona ${ }^{1}$, Selvia $^{2}$ \\ ${ }^{1,2}$ Sekolah Tinggi Ilmu Farmasi Riau (STIFAR RIAU) - Pekanbaru \\ Email Penulis Korespondensi $\left({ }^{\mathrm{K}}\right)$ : rdona1985@gmail.com \\ rdona1985@gmail.com ${ }^{1}, \underline{\text { Viasilvia348@gmail.com }}{ }^{2}$
}

\begin{abstract}
Hydroquinone is a chemical compound widely used in cosmetics that acts as a removal of black spots/spots on the face. The use of hydroquinone in cosmetics, according to BPOM regulations, is only allowed with a maximum level of $2 \%$. Excessive use of hydroquinone can cause pigment abnormalities in the face. The materials used in this study were hydroquinone BPFI, 96\% ethanol, absolute ethanol, sodium sulfate, methanol (HPLC grade), aquadest, ethyl acetate, and face cream samples (X and Y). Qualitative and quantitative analysis of hydroquinone content in both face cream samples was carried out by TLC and HPLC methods. The results of the qualitative analysis by TLC on both face cream samples (X and Y creams) showed that both samples had the same Rf value ${ }^{1}$ as the standard hydroquinone $\mathrm{Rf}$ while the HPLC chromatogram results of both samples had the same retention time as the standard hydroquinone. Simultaneously, the results of quantitative analysis on cream $\mathrm{X}$ samples contained hydroquinone of $3.06 \%$ and $\mathrm{Y}$ cream of $4.15 \%$. From these results, both face cream samples positive contained hydroquinone with levels $>2 \%$.
\end{abstract}

Keywords: Hydroquinone; Qualitative; Quantitative; TLC; HPLC

Article history :

Received: 30 May 2020

Received in revised form: 20 June 2020

Accepted: 10 October 2020

Available online: 1 December 2020 


\section{INTRODUCTION}

Hydroquinone (HQ) is a whitening component in cosmetic products that is only allowed in low levels ${ }^{1}$. According to the regulation of the Food and Drug Supervisory Agency (BPOM) based on the 2007 Public Warning regarding cosmetics containing hazardous substances and prohibited dyes, the use of $\mathrm{HQ}>2 \%$ in cosmetic preparations is prohibited and can lead to ill health ${ }^{2}$.

HQ has a synonym: 1,4-Benzenediol or 1,4-Dihydroxybenzene with the chemical formula $\mathrm{C}_{6} \mathrm{H}_{6} \mathrm{O}_{2}$ and a molecular weight of $110.11 \mathrm{~g} / \mathrm{mol}$. It is a solid white crystal with a boiling point at $285^{\circ}$ $\mathrm{C}$ at $0.9605 \mathrm{~atm}^{3}$. This compound has been used as a bleaching agent and was recently included by the European Commission in Annex II. This substance should not be part of the composition of cosmetic products due to its potential toxicity ${ }^{4}$.

Whitening cream is a type of cosmetic that is a mixture of chemicals and other ingredients with properties that can lighten black spots (brown) on the skin. The purpose of its long-term use is to eliminate or reduce hyperpigmentation on the skin ${ }^{5}$. The requirements for a safe whitening cream cosmetic product are to have a registration code from the Food and Drug Supervisory Agency of the Republic of Indonesia, include all compositions, including the expiration date, and do not contain dangerous ingredients such as mercury $(\mathrm{Hg})$, hydroquinone $>2 \%$ and retinoic acid/tretinoin ${ }^{6}$.

Use of HQ in cosmetic products for skin whitening and depigmentation of spots on the skin. This compound inhibits melanin synthesis by inhibiting the enzyme tyrosinase. The bleaching aspect can also be caused by HQ's interfering effect with the formation or degradation of melanosomes or by inhibiting DNA and RNA synthesis in melanocytes. HQ is considered highly cytotoxic to melanocytes and potentially mutagenic to mammalian cells ${ }^{7}$. HQ can affect health such as leukoderma, exogenous ochronosis, and in the long term can cause carcinogenesis ${ }^{8}$. DNA damage and mutation can also occur due to HQ oxidation to p-benzoquinone in the bone marrow ${ }^{9}$.

The identification and measurement of HQ have been made using various methods. The Thin Layer Chromatography (TLC) method can be used because it is more comfortable, and the equipment is simple ${ }^{10}$. For better qualitative and quantitative analysis, HPLC's best method is because it can perform better separation ${ }^{11}$.

Research by Gianti (2013) ${ }^{12}$, on the analysis of mercury content and quantitative analysis of hydroquinone by HPLC in cosmetic concoctions by doctors in Jakarta. From the results that have been tested, the results of the four samples show that the sample A cream contains hydroquinone with a level of $3,499 \%$, cream B of $3.561 \%$, cream C of $3.754 \%$, and cream D of $3.541 \%$. In this study, the qualitative and quantitative analysis of HQ compounds in the sample used TLC and HPLC methods. 


\section{METHOD}

\section{Sample Preparation}

The sample is a face cream that is sold in the market in the city of Pekanbaru. The sample was selected based on the purposive sampling method. Namely, the sampling was determined based on the researcher's criteria. For this sample, the criteria set were face cream samples that functioned as whitening, included in the category widely used by the public, were imported products that were not officially registered from the BPOM, caused a whitening effect on the face quickly, had a low price and had no marked marking complete on the packaging.

Sample preparation was carried out by weighing the sample as much as $2 \mathrm{~g}$, and then the sample was dissolved in $96 \%$ ethanol and heated at $60^{\circ} \mathrm{C}$ for 10 minutes while stirring and cooling. The solution is filtered on filter paper through which sodium sulfate is passed, add $25 \mathrm{ml}$ ad ethanol, and homogenized 13

\section{Qualitative Analysis}

The prepared sample was analyzed qualitatively using the Thin Layer Chromatography (TLC) method. The sample was spotted on the TLC plate using the eluent ratio of methanol: ethyl acetate (3: 7). As a reference standard, the BPFI hydroquinone was also placed on the TLC plate then the results were compared with the sample. Another qualitative analysis also used the HPLC method by comparing the retention time of the sample and the hydroquinone standard.

\section{Quantitative Analysis}

The quantitative analysis using the HPLC method begins with making a calibration curve for the HQ standard solution. A total of $5 \mathrm{mg}$ of HQ standard was dissolved in $5 \mathrm{ml}$ of absolute ethanol and homogenized. Made a standard solution concentration of 100; 200; 300; 400; and 500 ppm, then injected each as much as $20 \mu \mathrm{l}$ into the HPLC device with a UV-VIS detector using ODS as a column a flow rate of $0.75 \mathrm{ml} / \mathrm{min}$. The mobile phase used is a mixture of water/methanol solvent by elution gradient. Measurements were made using a wavelength of $300 \mathrm{~nm}$.

Sample preparation for quantitative analysis was carried out by weighing $1 \mathrm{~g}$ of each sample and dissolving it in $5 \mathrm{ml}$ of absolute ethanol, and homogenizing it. $0.2 \mathrm{ml}$ of the solution on the pipette and add $1 \mathrm{ml}$ ad ethanol so that the sample concentration becomes $10 \mathrm{mg} / \mathrm{ml}$. The solution is filtered with filter paper through which sodium citrate is passed to remove fat. The filtrate is injected as much as 20 $\mu 1$ into the HPLC device by first filtering it in a $0.45 \mu \mathrm{m}$ PTFE filter membrane. A UV-VIS detector was used with ODS as a column and a flow rate of $0.75 \mathrm{ml} / \mathrm{min}$. The mobile phase used is a mixture of water/methanol solvent by elution gradient. Measurements were made using a wavelength of $300 \mathrm{~nm}$.

\section{Data Analysis}

The data obtained from the results of the standard solution calibration are presented based on the analysis of the calibration curve with the regression equation: $Y=a+b x$, where $x$ is the hydroquinone concentration of the analyzed sample. 


\section{RESULTS}

From the appropriate criteria in the sample selection, two facial cream products were determined as samples, namely " $\mathrm{X}$ " face cream (a product made in China) and " $\mathrm{Y}$ " face cream (a product made in Malaysia). Both creams are imported products with incomplete's information on the leaflet on the packaging and are products that tend to sell well in the market because they have an immediate lightening effect and are suspected of containing hydroquinone with levels $>2 \%$.

The results of qualitative analysis by TLC showed that both samples had a value of $\mathrm{Rf}=0.7$ by using the ratio of eluent = methanol: ethyl acetate (3: 7), where the Rf value obtained was the same as the standard Rf of hydroquinone. The TLC method has advantages, including more comfortable and cheaper implementation and more straightforward equipment used. Besides, the TLC method has greater flexibility in selecting the mobile phase. Another qualitative analysis can also be concluded from the results of the HPLC chromatogram where the two samples have a retention time of about 4 minutes, and this is also the same as the hydroquinone standard, which has a retention time of about 4 minutes (Table $1)$.

Table 1. The retention time of the sample and standard

\section{Sample}

\begin{tabular}{cc} 
& Waktu Retensi (menit) \\
\hline Sampel X & 4,473 \\
Sampel Y & 4,664 \\
Standar HQ & 4,814 \\
\hline
\end{tabular}

In quantitative analysis, the results of the calibration of the HQ standard solution obtained a regression equation, $y=23642 x+461520$ with a correlation coefficient of 0.9908 . The hydroquinone content of the two samples was carried out by entering the area in the chromatogram results of the two samples at the $\mathrm{y}$ value of the regression equation so that the $\mathrm{x}$ value in the equation was obtained as the hydroquinone concentration. From the results of these calculations, sample $\mathrm{X}$ face cream contains hydroquinone of $3.06 \%$, and sample $\mathrm{Y}$ face cream contains $4.15 \%$ hydroquinone. This level exceeds the level limit that should be contained in cosmetics that are still allowed, which is not more than $2 \%$. 


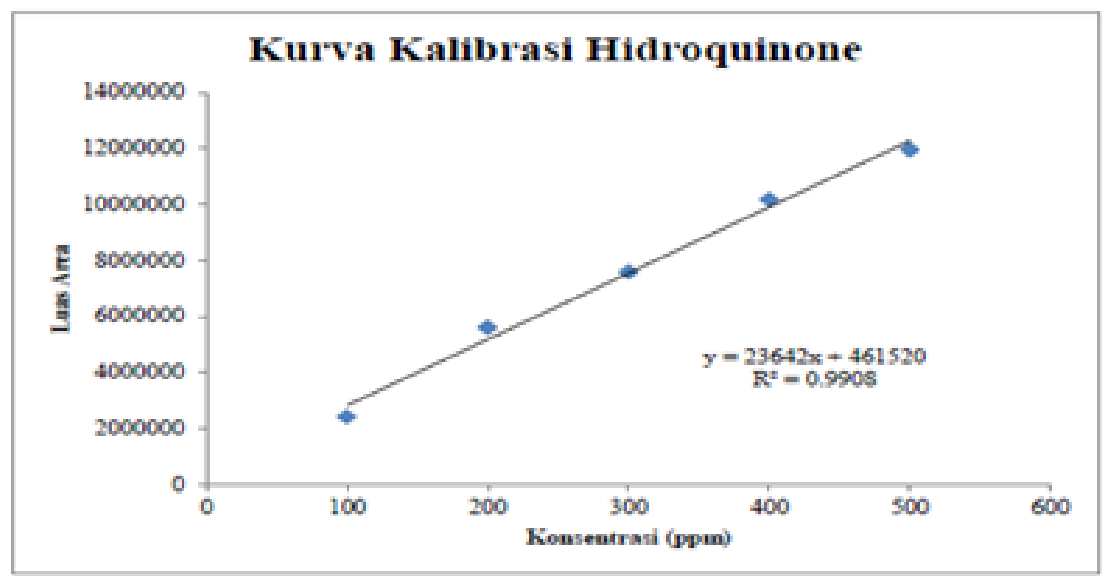

\begin{tabular}{|c|c|}
\hline Konsentrasi & Luas Area \\
\hline 100 & 2424198 \\
\hline 200 & 5612294 \\
\hline 300 & 7590771 \\
\hline 400 & 10184902 \\
\hline 500 & 11959123 \\
\hline
\end{tabular}

Figure 1. Hydroquinone standard calibration curve

\section{DISCUSSION}

The qualitative analysis in this test aims to identify hydroquinone content in $\mathrm{X}$ and $\mathrm{Y}$ face samples. The test was carried out using the TLC method with the mobile phase methanol: water. Hydroquinone is a polar compound; to attract this compound, it can be extracted with a polar compound. The initial test carried out on the sample that has been prepared is dissolved using $96 \%$ ethanol solvent. The use of ethanol as a solvent is due to hydroquinone's solubility, which dissolves in polar solvents, one of which is ethanol. The Rf value obtained from the two samples, namely, both samples have an Rf value of 0.7 , and the standard hydroquinone also has an $\mathrm{Rf}$ value of 0.7 .

To prove hydroquinone's presence and what levels were contained in samples "X" and "Y," it was followed by quantitative analysis using HPLC. HPLC (High-Performance Liquid Chromatography) is a chromatography technique for liquids accompanied by high pressure. Compared to other methods, the advantages of this method are the relatively short analysis time, high accuracy and precision, and the column and developer solvent can be used many times. The mobile phase used is the gradient elution method. This quantitative analysis begins by looking for the standard calibration curve for hydroquinone. Standards are made with a concentration of 100 ppm, 200 ppm, 300 ppm, 400 ppm, and $500 \mathrm{ppm}$. The hydroquinone standard is then injected into the HPLC tool with a wavelength of $300 \mathrm{~nm}$, the mobile phase of water: methanol using the gradient elution method. The results obtained by the value of $r=0.9908$ with a linear regression equation $y=23642 x+461520$. The value of $r=0.9908$ indicates that the correlation coefficient's value is close to 1, meaning that the calibration curve of the obtained hydroquinone standard gives a good correlation value. The results showed that the face cream "X" 
contained 3.06\% hydroquinone and the "Y" face cream contained $4.15 \%$ hydroquinone. Of the two samples tested, all of them contained hydroquinone that exceeded the determined level limit, which was a maximum of $2 \%$.

\section{CONCLUSIONS}

Based on the research that has been done, it can be concluded that the cream tested qualitatively with TLC contains hydroquinone and is tested by the HPLC method. The cream contains levels that exceed the allowable level, namely a maximum of $2 \%$, for the sample $\mathrm{X}$ cream contains hydroquinone with a level of $3.06 \%$. Moreover, the Y cream sample contains hydroquinone with a content of $4.15 \%$.

\section{REFERENCES}

1 Zukepli M, Wihdah N, Omar W, Atikah WS, Zakaria, Raihan S. Assessment on Hyroquinone in Selected Cosmetic Cream and Toner via High Performance Liquid Chromatography and UltraViolet Visible Detector Spectrometry. Malaysian Journal of Analytical Sciences 2015; 19: 824 830 .

2 BPOM RI. Kosmetik Mengandung Bahan Berbahaya dan Zat Warna Yang Dilarang: Keputusan Kepala Badan Pengawas Obat dan Makanan Republik Indonesia No. HK.00.01.432.6081. 2007.

3 Sigma-Aldrich. Hydroquinone ReagentPlus ${ }^{\circledR}, \quad \geq 99 \%$. 2018.https://www.sigmaaldrich.com/catalog/product/aldrich/240125?lang=en\&region=ID .

4 Commission Regulation (EU). Regulations No. 344/2013 of 4 April 2013 Amending Annexes II, III, V and VI to Regulation (EC) No 1223/2009 of the European Parliament and the Council on Cosmetic Products. OJEU, 2013, L114/1. 2013. 2013.http://www.eurlex.europa.eu/LexUriServ/LexUriServ.do?uri=OJ:L:2013:114:0001:0059: EN:PDF.

5 Anief M. Farmasetika. UGM Press: Yogyakarta, 2012.

6 BPOM RI. Public Warning / Peringatan Nomor KH. 00.01.433.6147 Tentang Kosmetik Mengandung Bahan Berbahaya Dan Zat Warna Yang Dilarang. 2007.

7 Gimeno P, Maggio AF, Bancilhon M, Lassu N, Gornes H, Brenier C et al. HPLC-UV method for the identification and screening of hydroquinone, ethers of hydroquinone and corticosteroids possibly used as skin-whitening agents in illicit cosmetic products. Journal of Chromatographic Science 2016; 54: 343-352.

8 Thongchai W, Liawruangrath B, Liawruangrath S. High-performance liquid chromatographic determination of arbutin in skin-whitening creams and medicinal plant extracts. Journal of Cosmetic Science 2007; 58: 35-44.

9 Westerhof W, Kooyers TJ. Hydroquinone and its analogues in dermatology - a potential health risk. Journal of Cosmetic Dermatology 2005; 4: 55-59.

10 Rohman A. Kromatografi untuk analisis obat. 1st ed. Graha Ilmu: Yogyakarta, 2009.

11 Lin WC, Lin ST, Shu SL. Comparison of analyses of surfactants in cosmetics using highperformance liquid chromatography and high-performance capillary electrophoresis. Journal of Surfactants and Detergents 2000; 3: 67-72.

12 Gianti. Analisis Kandungan Merkuri Dan Hidrokuinon Dalam Kosmetik Krim Racikan Dokter. FKM UIN Hidayatullah Jakarta. 2013. 